\title{
Effect of Different Nitrogen Levels and Spacing on Growth and Flowering of Iris (Iris orientalis Mill.) cv. 'Frigia'
}

\author{
Tamanna Verma*, B.P. Sharma and Mallika Thakur \\ Department of Floriculture and Landscape Architecture, Dr YS Parmar University of \\ Horticulture and Forestry, Nauni, Solan 173230 Himachal Pradesh, India \\ *Corresponding author
}

\begin{tabular}{|c|c|}
\hline & A B S T R A C T \\
\hline & \multirow{6}{*}{$\begin{array}{l}\text { The present investigations were carried out at the research farm of Department of } \\
\text { Floriculture and Landscape Architecture, Dr YS Parmar University of Horticulture and } \\
\text { Forestry, Nauni, Solan, Himachal Pradesh during } 2018 \text { on cultivar Frigia. The experiment } \\
\text { was laid out in a Randomized Block Design (factorial) using four levels of nitrogen i.e. } 0 \\
15,30 \text { and } 45 \mathrm{~g} / \mathrm{m}^{2} \text { with three plant spacing of } 20 \times 20 \mathrm{~cm}, 20 \times 25 \mathrm{~cm} \text { and } 20 \times 30 \mathrm{~cm} \\
\text { each being replicated thrice. The results revealed that wider spacing } 20 \times 30 \mathrm{~cm} \text { and } \\
\text { fertilized with } 30 \mathrm{~g} / \mathrm{m}^{2} \text { recorded maximum values for number of leaves per plant }(10.07) \\
\text { plant height }(96.90 \mathrm{~cm}) \text {, spike length }(68.36 \mathrm{~cm}) \text {, plant spread }(18.33 \mathrm{~cm}) \text {, number of } \\
\text { florets per spike }(4.53) \text {, floret size }(14.12 \mathrm{~cm}) \text {, stem diameter }(7.3 \mathrm{~mm}) \text {, fresh weight of cut } \\
\text { stems }(45.41 \mathrm{~g}) \text {, vase life }(11.47 \text { days) and duration of flowering }(10.33 \text { days). However } \\
\text { minimum days taken for visible bud formation }(62.40 \text { days) and for first flower opening } \\
\text { ( } 73.60 \text { days) was recorded in plants without application of nitrogen i.e. control with plant } \\
\text { spaced at } 20 \times 30 \mathrm{~cm} \text { apart. Therefore, plants supplied with } 30 \mathrm{~g} \mathrm{~N} / \mathrm{m}^{2} \text { spaced at } 20 \times 30 \\
\text { cm apart recorded maximum values in terms of most of the growth and flowering } \\
\text { parameters in Iris orientalis Mill. cv. 'Frigia'. }\end{array}$} \\
\hline Keywords & \\
\hline $\begin{array}{l}\text { Nitrogen, Spacing, } \\
\text { Iris orientalis, } \\
\text { Growth and } \\
\text { Flowering }\end{array}$ & \\
\hline Article Info & \\
\hline $\begin{array}{l}\text { Accepted: } \\
\text { 17 April } 2019 \\
\text { Available Online: } \\
10 \text { May } 2019\end{array}$ & \\
\hline & \\
\hline
\end{tabular}

\section{Introduction}

Iris belongs to family Iridaceae and is commonly grown as commercial cut flower crop. They are commercially exploited for their showy- flowers, hence the Greek name has been applied for the sparkling hues of the flower colors. These are perennial plants, growing from creeping rhizomes or bulbs. These are naturally distributed throughout the temperate and sub- tropical zones of the Northern Hemisphere (De and Bhattacharjee, 2003). It contains little fragrance and is also valued for its medicinal uses. Therefore, there is a strong need to boost the production of this flower crop. The increased productivity of flower crop can appreciably be achieved through adoption of improved cultural practices. It has been established that spacing and nutrients play an important role in overall improvement of growth, yield and flower quality in many flower crops. Nutrients such as nitrogen play a major role in the growth and development of plants (Scott, 2008). Nitrogen as an essential element that improves the chemical and biological 
properties of soil, and thereby stimulates the production of higher yield in plants. It increases the vegetative growth and subsequently quality of foliage by promoting carbohydrate synthesis. Adequate plant spacing is another important practice for providing good open position for availability of moisture and nutrients with sufficient sunlight for successful crop production and quality flowers (Sanjib et al., 2000). Hence, a study was undertaken to investigate the role of nitrogen and spacing on the growth and flowering of Iris orientalis Mill. cv. 'Frigia'.

\section{Materials and Methods}

The present investigations were undertaken at experimental farm of Department of Floriculture and Landscape Architecture, Dr YS Parmar University of Horticulture and Forestry, Nauni, Solan (HP) during 2018. There were twelve treatment combinations of three spacings $(20 \times 20 \mathrm{~cm}, 20 \times 25 \mathrm{~cm}$ and $20 \times 30 \mathrm{~cm})$ and four levels of nitrogen $(0,15$, 30 and $45 \mathrm{~g} / \mathrm{m}^{2}$ ) and the experiment was laid out in a factorial randomized block design with three replications. The healthy, uniform and disease free rhizomes were planted in beds of $1 \times 1 \mathrm{~m}$ size at the specified spacings.

A basal dose of $5 \mathrm{~kg}$ well rotten farm yard manure (FYM) along with half of nitrogen and full amount of phosphorous $\left(30 \mathrm{~g} / \mathrm{m}^{2}\right)$ and potassium $\left(20 \mathrm{~g} / \mathrm{m}^{2}\right)$ was applied at the time of planting while another half dose of nitrogen was given after one month of planting. Calcium nitrate was used as a source of nitrogen $(16 \% \mathrm{~N})$ while in case of phosphorous it was Single Super Phosphate $\left(\begin{array}{lll}16 & \% & \mathrm{P}_{2} \mathrm{O}_{5}\end{array}\right)$ and potassium applied as Muriate of Potash $\left(\begin{array}{llll}60 & \% & \mathrm{~K}_{2} \mathrm{O}\end{array}\right)$. The observations on different growth and flowering characters were recorded from time to time on randomly selected five competitive plants per plot in each replication.

\section{Results and Discussion}

The results obtained from the present investigation as well as relevant discussion have been summarized under the following heads:

\section{Days taken for visible flower bud formation}

Nitrogen dose@ $30 \mathrm{~g} / \mathrm{m}^{2}$ took maximum days to bud formation (64.73 days) and minimum days taken to bud formation (62.71 days) noticed in those plants without nitrogen. The fact behind the delayed initiation of flower buds was mainly due to the prolonged vegetative phase because nitrogen had synergistic effect (Sheoran et al., 2016). As regards the effect of spacing, lesser time for days taken to visible bud formation (63.62 days) was recorded in a plant spacing of $20 \times 30 \mathrm{~cm}$ and more time for visible bud formation (64.17 days) were recorded at $20 \times 20 \mathrm{~cm}$. The early bud formation under wider spacing can be ascribed to availability of sufficient space and better nutrient availability to the plants. It might be due to proper planting procedures, moisture and abundant light availability that might have helped in early formation of bud. The interaction of nitrogen and spacing influenced the days taken for visible bud formation. Minimum days for visible bud formation (62.40 days) were recorded in those plants without nitrogen i.e. control in a spacing of $20 \times 30 \mathrm{~cm}$ However, maximum days for visible bud formation (65.00 days) were recorded in plants with application of nitrogen @ $30 \mathrm{~g} / \mathrm{m}^{2}$ at a spacing of $20 \times 20 \mathrm{~cm}$. It could be due to availability of more space facilitating improved aeration and better penetration of light which in turn might have increased photosynthetic activity and translocation of assimilates to growing parts resulting in better availability of nutrients (Ram et al., 2012). 


\section{Days taken to first flower opening}

Minimum days taken to flower opening (73.80 days) were observed in plants without application of nitrogen i.e. control and maximum days taken to flower opening $(75.80$ days $)$ recorded with $30 \mathrm{~g} / \mathrm{m}^{2}$. Increasing levels of nitrogen were marked to delay the heading significantly and thereby prolonged the duration of flowering. Higher doses of nitrogen may have caused excessive vegetative growth adversely affecting days taken to flower. Such delay in flowering due to application of nitrogen was also reported by Rani et al., (2005). Data pertaining to the effect of spacing exhibited significant effect on days taken to first flower opening. However, among the different spacing tested, minimum days taken to first flower opening (74.68 days) was found in plants spaced at $20 \times 30 \mathrm{~cm}$, whereas, maximum days $(75.32$ days) were noticed in spacing of $20 \times 20 \mathrm{~cm}$. Similar results were obtained by Tyagi et al., (2008) in tuberose. The interaction of nitrogen and plant spacing influenced the days taken to first flower opening. Minimum days (73.60 days) were noticed in plants receiving no nitrogen i.e. control with a plant spacing of $20 \times 30 \mathrm{~cm}$. However, maximum days $(76.00$ days) were recorded with $30 \mathrm{~g} \mathrm{~N} / \mathrm{m}^{2}$ with a plant spacing of $20 \times 20 \mathrm{~cm}$.

\section{Number of leaves per plant}

Nitrogen, plant spacing and their interactions influenced the number of leaves per plant. Amongst nitrogen levels, maximum numbers of leaves per plant (9.93) were recorded in plants supplied with $30 \mathrm{~g} \mathrm{~N} / \mathrm{m}^{2}$. Minimum number of leaves per plant (8.67) was observed in plants without nitrogen. An increase in number of leaves with the application of higher doses of nitrogen might be due to the fact that nitrogen is an essential part of nucleic acid which plays a vital role in promoting the plant growth and number of leaves (Patel et al., 2006). Highest number of leaves per plant (9.67) was recorded with a spacing of $20 \times 30 \mathrm{~cm}$. Minimum number of leaves per plant (9.27) was observed in a spacing of $20 \times 20 \mathrm{~cm}$. It could be due to availability of more space facilitating improved aeration and better penetration of light which in turn might have increased photosynthetic activity and translocation of assimilates to growing parts resulting in better availability of nutrients (Ram et al., 2012). These findings are in confirmation with the results of Bhande et al., (2015) in gladiolus where maximum number of leaves per plant (16.03) was found under wider spacing i.e. $45 \times 15 \mathrm{~cm}$. Nitrogen and spacing when applied in combination influenced the number of leaves per plant. An application of nitrogen and spacing improved the number of leaves per plant. Maximum number of leaves per plant (10.07) was recorded with a $30 \mathrm{~g} \mathrm{~N} / \mathrm{m}^{2}$ and a spacing of $20 \times 30 \mathrm{~cm}$. However, minimum number of leaves per plant (8.27) were recorded in a spacing of $20 \times 20 \mathrm{~cm}$ with no application of nitrogen i.e. control. This might be due to optimum spacing with fertilizer doses encouraged for availability of more nutrients, light interference and soil moisture (Munikrishnappa, 1996 and Bhatacharjee et al., 1994) in tuberose.

\section{Plant height (cm)}

Tallest plant $(95.25 \mathrm{~cm})$ found with an application of $30 \mathrm{~g} \mathrm{~N} / \mathrm{m}^{2}$ and it proved significantly higher over all other treatments. Minimum plant height $(87.28 \mathrm{~cm})$ was recorded in those plants receiving no nitrogen. The maximum plant height obtained at higher doses of nitrogen revealed that nitrogen had an encouraging effect on plant height as it forms an important constituent of protein, which is essential for the formation of protoplasm, thus, affecting the cell division and cell enlargement and ultimately leads to better vegetative growth (Sheoran et al., 
2016). Among the different spacing tested, maximum plant height $(92.97 \mathrm{~cm})$ was recorded with a spacing of $20 \times 30 \mathrm{~cm}$, whereas, it was minimum $(91.07 \mathrm{~cm})$ in plant spaced $20 \times 20 \mathrm{~cm}$ apart. Wider spacing provided more space to the plant to derive nutrients from the soil and reduced the competition between plants for nutrients and light (Yadav and Singh, 1996). Reduction in plant height in closer spacing may be due to greater competition between plants for various factors. The interactions of nitrogen and plant spacing influenced the plant height. Taller plants $(96.90 \mathrm{~cm})$ were obtained with an application of $30 \mathrm{~g} \mathrm{~N} / \mathrm{m}^{2}$ with spacing of $20 \times 30 \mathrm{~cm}$. However, minimum plant height $(86.10 \mathrm{~cm})$ was recorded in plants without nitrogen spaced at $20 \times 20 \mathrm{~cm}$ apart. This might be due to optimum spacing with fertilizer doses encouraged for availability of more nutrients, light interference and soil moisture (Munikrishnappa, 1996 and Bhatacharjee et al., 1994).

\section{Spike length $(\mathrm{cm})$}

Results obtained for different applications of nitrogen, spacing and their interactions influenced the spike length. Among the different applications of nitrogen, maximum spike length $(67.88 \mathrm{~cm})$ was recorded with 30 $\mathrm{g} \mathrm{N} / \mathrm{m}^{2}$. Minimum spike length $(53.04 \mathrm{~cm})$ was recorded in those plants without application of nitrogen. It was due to enhancement in growth rate by application of nitrogen. This finding is in agreement with Bijimol and Singh (2001) and Kumar et al., (2002) also recorded longest spikes under higher nitrogen doses in tuberose and gladiolus. A perusal of data in Table 1 showed the highest spike length $(65.29 \mathrm{~cm})$ at plant spacing of $20 \times 30 \mathrm{~cm}$ and a minimum spike length $(60.45 \mathrm{~cm})$ was recorded in plant spacing of $20 \times 20 \mathrm{~cm}$. This might be due to the fact that the closer spacing hampered intercultural operations and as such more competition arises among the plants for nutrients, air, and light. As a result, plant becomes weaker, thinner and consequently affects the growth of the plant. Interactions of nitrogen with plant spacing influenced the spike length. Maximum spike length (68.36 $\mathrm{cm}$ ) was observed with application of $30 \mathrm{~g}$ $\mathrm{N} / \mathrm{m}^{2}$ with spacing of $20 \times 30 \mathrm{~cm}$. However, minimum spike length $(48.93 \mathrm{~cm})$ was noticed in those plants without nitrogen and spaced at $20 \times 20 \mathrm{~cm}$ apart.

\section{Plant spread (cm)}

Maximum plant spread $(17.97 \mathrm{~cm})$ was noticed in plants supplied with $30 \mathrm{~g} \mathrm{~N} / \mathrm{m}^{2}$. However, minimum plant spread $(13.75 \mathrm{~cm})$ was recorded in control. As regards the effect of plant spacing, maximum plant spread $(16.73 \mathrm{~cm})$ was recorded in a spacing of $20 \times 30 \mathrm{~cm}$ which was found to be superior over other treatments. Minimum plant spread $(15.49 \mathrm{~cm})$ was noticed in spacing of $20 \times 20$ $\mathrm{cm}$. An interaction of nitrogen and spacing influenced the plant spread. Maximum plant spread $(18.33 \mathrm{~cm})$ was recorded with $30 \mathrm{~g}$ $\mathrm{N} / \mathrm{m}^{2}$ at spacing of $20 \times 30 \mathrm{~cm}$. However, minimum plant spread $(12.18 \mathrm{~cm})$ was recorded in those plants receiving no nitrogen application $\left(\mathrm{N}_{1}\right)$ with spacing of $20 \times 20 \mathrm{~cm}$.

\section{Number of florets per spike}

A significant influence of nitrogen, plant spacing and their interactions was observed on number of florets per spike. Maximum number of florets per spike (4.40) was observed with $30 \mathrm{~g} \mathrm{~N} / \mathrm{m}^{2}$. However, minimum numbers of florets per spike (3.13) were observed in those plants without nitrogen. Maximum number of florets per spike was obtained with the higher doses of nitrogen application which might be the fact that, applied nitrogen had significantly increased the growth parameters and synthesized more plant metabolites ultimately leading to 
increased flower production (Chan, 1959). The present findings of research are in close agreement with the results of Regar et al., (2016) and Lehri et al., (2011) in gladiolus. Among the different spacing used, maximum number of florets per spike (4.17) was recorded in a spacing of $20 \times 30 \mathrm{~cm}$ and it was found to be significantly superior over all other treatments. Minimum number of florets per spike (3.75) was noticed in plant spaced at $20 \times 20 \mathrm{~cm}$ apart. The reason behind this could be better leaf growth in wider spacing that might have accelerated the photosynthesis during vegetative period and further translocation of photosynthates to various metabolic sinks during reproductive period might have been responsible for improvement in production of florets per spike. These results are in agreement with and Khalaj and Edrisi (2012) in tuberose. Interaction of nitrogen and spacing influenced the number of florets per spike. Maximum numbers of florets per spike (4.47) were recorded with 30 $\mathrm{g} \mathrm{N} / \mathrm{m}^{2}$ in a plants with a spacing of $20 \times 30$ $\mathrm{cm}$. Whereas, minimum number of florets per spike (2.60) were recorded in plants receiving no nitrogen and with spacing of $20 \times 20 \mathrm{~cm}$. Similar, results were obtained by Padaganur et al., (2005) in tuberose and Bijimol and Singh (2001) in gladiolus.

\section{Floret size (cm)}

Nitrogen applications improved the floret size. Florets of larger sizes $(14.06 \mathrm{~cm})$ were obtained with $30 \mathrm{~g} \mathrm{~N} / \mathrm{m}^{2}$ application which was proved to be significantly superior over all other treatments. Minimum floret size $(11.65 \mathrm{~cm})$ noticed in those plants without nitrogen. As regards the effect of spacing, maximum floret size $(13.47 \mathrm{~cm})$ was noticed in a spacing of $20 \times 30 \mathrm{~cm}$ which proved significantly superior over all other treatments. However, minimum floret size $(12.95 \mathrm{~cm})$ was recorded in spacing of $20 \times 20$ $\mathrm{cm}$. The present results indicated that, plants with widest spacing recorded the highest flower diameter which might be due to the fact that wider spacing provides sufficient space between the plants resulting in absorption of optimum amount of nutrients with sufficient light leading to better photosynthesis and translocation of assimilates in the storage organs. Similar results were also recorded by Ramachandrudu and Tangam (2007), Dogra et al., (2012) in gladiolus. The interactions between nitrogen and spacing influenced the floret size. Maximum floret size $(14.12 \mathrm{~cm})$ was recorded with $30 \mathrm{~g} \mathrm{~N} / \mathrm{m}^{2}$ application in a spacing of $20 \times 30 \mathrm{~cm}$. Florets of minimum size $(10.87$ $\mathrm{cm})$ were noticed in plants without nitrogen application when spaced at $20 \times 20 \mathrm{~cm}$ apart.

\section{Stem diameter (mm)}

Maximum stem diameter $(7.1 \mathrm{~mm})$ was recorded in plants supplied with $30 \mathrm{~g} \mathrm{~N} / \mathrm{m}^{2}$. However, minimum stem diameter $(5.7 \mathrm{~mm})$ was observed in those plants receiving no nitrogen application. The increase in growth characters and yield components from increased nitrogen level might be due to the role of nitrogen in stimulating vegetative growth. The hypothesis is that nitrogen is a constituent of protein, nucleic acids and nucleotides that are essential to the metabolic function of plants Bijimol and Singh 2001. Amongst the different spacing used, maximum stem diameter $(6.6 \mathrm{~mm})$ was found in a spacing of $20 \times 30 \mathrm{~cm}$ whereas, it was minimum $(6.1 \mathrm{~mm})$ in a spacing of $20 \times 20 \mathrm{~cm}$. The plants spaced with wider levels produced the maximum stem diameter might be due to availability of more nutrients and light at wider spacings which ultimately increased the rate of net photosynthesis and translocation of assimilates to the storage organs Dogra et al., 2012. Maximum stem diameter $(0.73 \mathrm{~cm})$ was recorded in plants supplied with $30 \mathrm{~g} \mathrm{~N} / \mathrm{m}^{2}$ at a spacing of $20 \times 30 \mathrm{~cm}$. However, minimum stem diameter $(0.55 \mathrm{~cm})$ was noticed in plants 
receiving no nitrogen and in a spacing of $20 \times 20 \mathrm{~cm}$.

\section{Fresh weight of cut stems (g)}

Maximum fresh weight of stem (44.36 g) was obtained in plants supplied with $30 \mathrm{~g} \mathrm{~N} / \mathrm{m}^{2}$ and it was found to be significantly higher over all other treatments. Minimum weight of fresh cut stems ( $36.72 \mathrm{~g}$ ) was noticed in those plants without nitrogen. Plants supplied with higher nitrogen doses recorded the highest weight. It might be due to the supply of abundant nitrogen which helped in increasing assimilates that are necessary for increasing the weight (Sheoran et al., 2016). Similar kind of an increase in flower weight with the application of higher doses of fertilizers was reported by Kadu et al., (2009) in tuberose. As regards the effect of spacing, maximum fresh weight of cut stems (42.37 g) was recorded in a spacing of $20 \times 30 \mathrm{~cm}$, whereas, it was minimum (39.66 g) in a spacing of $20 \times 20 \mathrm{~cm}$. Present finding are in conformity with the findings of Ramachandrudu and Tangam (2007) in gladiolus. Weight of the stem was found to be directly proportional to thickness of stem. Greater the thickness of stem more is the weight of the stem. The fact that the weight of the stem depends upon the thickness of the stem has been corroborated by the finding of Kumar and Singh (1998) in tuberose. Interaction between nitrogen and spacing influenced the fresh weight of cut stems. Maximum weight $(45.41 \mathrm{~g})$ was recorded in plants receiving $30 \mathrm{~g} \mathrm{~N} / \mathrm{m}^{2}$ in a plant spacing of $20 \times 30 \mathrm{~cm}$. However, minimum weight $(34.01 \mathrm{~g})$ was observed in plants with no application of nitrogen application at a spacing of $20 \times 20 \mathrm{~cm}$.

\section{Vase life (days)}

Nitrogen applications increased the vase life of cut flowers. Maximum vase life (11.09 days) was observed in each stem obtained from plants supplied with $30 \mathrm{~g} \mathrm{~N} / \mathrm{m}^{2}$. Minimum vase life (8.36 days) was observed in plants with no nitrogen application. Bijimol and Singh (2000) observed that the nitrogen is essential constituent of various proteins and take active part in various metabolic processes which might have some role in augmenting the vase life of cut gladioli. Nitrogen applied in varied levels affected the vase life significantly. Increasing levels of nitrogen consistently proved significantly superior in prolonging the vase life of tuberose (Gangwar et al., 2012). Among the different spacing studied, maximum vase life (10.20 days) was noticed at a spacing of $20 \times 30 \mathrm{~cm}$ whereas, it was minimum $(9.75$ days) in plants spaced $20 \times 20 \mathrm{~cm}$ apart.

These results are in close agreement with the findings of Bijimol and Singh (2000) who observed that the spike harvested from the wider spacing absorbed maximum water during vase life of cut gladioli and the widest spacing recorded highest vase life as compared to closest spacing. The interactions between nitrogen and spacing influenced the vase life. Maximum vase life (11.47 days) was observed in plants supplied with $30 \mathrm{~g}$ $\mathrm{N} / \mathrm{m}^{2}$ at a spacing of $20 \times 30 \mathrm{~cm}$. However, minimum vase life (7.87 days) was observed in those plants with no nitrogen being spaced at $20 \times 20 \mathrm{~cm}$ apart. Similar results were obtained by Khalaj and Edrisi (2012) in tuberose. This might be due to optimum spacing with fertilizer doses encouraged for availability of more nutrients, light interference and soil moisture (Munikrishnappa, 1996 and Bhatacharjee et al., 1994)

\section{Duration of flowering (days)}

The study reveals that nitrogen application significantly increased flowering duration and it was maximum (10.16 days) in those plants receiving $30 \mathrm{~g} \mathrm{~N} / \mathrm{m}^{2}$. 
Table.1 Effect of different nitrogen levels and spacing on growth and flowering of Iris (Iris orientalis Mill.) cv. 'Frigia'

\begin{tabular}{|c|c|c|c|c|c|c|c|c|c|c|c|c|}
\hline Treatments & $\begin{array}{l}\text { Days taken for } \\
\text { visible flower } \\
\text { bud formation }\end{array}$ & $\begin{array}{lr}\text { Days } & \text { taken } \\
\text { for } & \text { first } \\
\text { flower } & \\
\text { opening } & \\
\end{array}$ & $\begin{array}{l}\text { Number } \\
\text { of leaves } \\
\text { per plant }\end{array}$ & $\begin{array}{l}\text { Plant } \\
\text { height } \\
\text { (cm) }\end{array}$ & $\begin{array}{l}\text { Spike } \\
\text { length } \\
(\mathrm{cm})\end{array}$ & $\begin{array}{l}\text { Plant } \\
\text { spread } \\
(\mathrm{cm})\end{array}$ & $\begin{array}{l}\text { Number } \\
\text { of florets } \\
\text { per spike }\end{array}$ & $\begin{array}{l}\text { Floret } \\
\text { size } \\
(\mathbf{c m})\end{array}$ & $\begin{array}{l}\text { Stem } \\
\text { diameter } \\
(\mathrm{mm})\end{array}$ & $\begin{array}{l}\text { Fresh wt. } \\
\text { of cut } \\
\text { stems }(g)\end{array}$ & $\begin{array}{l}\text { Vase } \\
\text { life } \\
\text { (days) }\end{array}$ & $\begin{array}{l}\text { Duration of } \\
\text { flowering } \\
\text { (days) }\end{array}$ \\
\hline \multicolumn{13}{|c|}{ Nitrogen $\left(\mathrm{g} / \mathrm{m}^{2}\right)$} \\
\hline$N_{1}(0)$ & 62.71 & 73.80 & 8.67 & 87.28 & 53.04 & 13.75 & 3.13 & 11.65 & 5.7 & 36.72 & 8.36 & 7.80 \\
\hline $\mathbf{N}_{2}(15)$ & 64.22 & 75.04 & 9.40 & 90.98 & 63.32 & 15.50 & 4.07 & 13.28 & 6.0 & 40.73 & 9.62 & 9.02 \\
\hline $\mathbf{N}_{3}(\mathbf{3 0})$ & 64.73 & 75.80 & 9.93 & 95.25 & 67.88 & 17.97 & 4.40 & 14.06 & 7.1 & 44.36 & 11.09 & 10.16 \\
\hline $\mathbf{N}_{4}(45)$ & 64.20 & 75.42 & 9.64 & 94.74 & 66.41 & 17.28 & 4.18 & 13.72 & 6.6 & 42.27 & 10.84 & 9.73 \\
\hline $\mathrm{CD}_{0.05}$ & 4.40 & 0.36 & 0.22 & 0.17 & 1.37 & 0.61 & 0.18 & 0.30 & 0.02 & 0.79 & 0.23 & 0.21 \\
\hline \multicolumn{13}{|c|}{ Spacing (cm) } \\
\hline$S_{1}(20 \times 20)$ & 64.17 & 75.32 & 9.27 & 91.07 & $6 . .45$ & 15.49 & 3.75 & 12.95 & 6.1 & 39.66 & 9.75 & 8.75 \\
\hline$S_{2}(20 \times 25)$ & 64.12 & 75.05 & 9.30 & 92.15 & 62.24 & 16.16 & 3.92 & 13.11 & 6.3 & 41.03 & 9.98 & 9.22 \\
\hline $\mathrm{S}_{3}(20 \times 30)$ & 63.62 & 74.68 & 9.67 & 92.97 & 65.29 & 16.73 & 4.17 & 13.47 & 6.6 & 42.37 & 10.20 & 9.57 \\
\hline $\mathrm{CD}_{0.05}$ & 0.35 & 0.31 & 0.19 & 0.15 & 1.19 & 0.53 & 0.16 & 0.26 & 0.02 & 0.68 & 0.20 & 0.19 \\
\hline \multicolumn{13}{|c|}{ Interaction $(\mathrm{N} \times \mathrm{S})$} \\
\hline $\mathbf{N}_{1} \mathbf{S}_{1}$ & 62.73 & 73.80 & 8.27 & 86.10 & 48.93 & 12.18 & 2.60 & 10.87 & 5.5 & 34.01 & 7.87 & 7.60 \\
\hline $\mathbf{N}_{1} \mathbf{S}_{2}$ & 63.00 & 74.00 & 8.47 & 87.75 & 51.42 & 14.19 & 3.00 & 11.68 & 5.6 & 36.72 & 8.40 & 7.80 \\
\hline $\mathbf{N}_{1} \mathbf{S}_{3}$ & 62.40 & 73.60 & 9.27 & 88.01 & 58.75 & 14.88 & 3.80 & 12.41 & 6.0 & 39.44 & 8.80 & 8.00 \\
\hline $\mathbf{N}_{2} \mathbf{S}_{1}$ & 64.80 & 75.80 & 9.40 & 90.03 & 59.25 & 15.22 & 4.00 & 13.17 & 5.5 & 39.83 & 9.20 & 8.40 \\
\hline $\mathbf{N}_{2} \mathbf{S}_{2}$ & 63.73 & 74.40 & 9.20 & 90.97 & 63.01 & 15.07 & 4.07 & 13.22 & 6.0 & 40.74 & 9.80 & 8.87 \\
\hline $\mathbf{N}_{2} \mathbf{S}_{3}$ & 64.13 & 74.93 & 9.60 & 91.93 & 67.71 & 16.21 & 4.13 & 13.44 & 6.5 & 41.63 & 9.87 & 9.80 \\
\hline $\mathbf{N}_{3} \mathrm{~S}_{1}$ & 64.80 & 76.00 & 9.87 & 92.88 & 67.58 & 17.40 & 4.27 & 14.06 & 6.7 & 43.16 & 10.80 & 9.93 \\
\hline $\mathbf{N}_{3} \mathbf{S}_{2}$ & 65.00 & 75.87 & 9.87 & 95.97 & 67.70 & 18.19 & 4.40 & 14.00 & 7.1 & 44.49 & 11.00 & 10.20 \\
\hline $\mathbf{N}_{3} \mathrm{~S}_{3}$ & 64.40 & 75.53 & 10.07 & 96.90 & 68.36 & 18.33 & 4.53 & 14.12 & 7.3 & 45.41 & 11.47 & 10.33 \\
\hline $\mathbf{N}_{4} \mathbf{S}_{1}$ & 64.33 & 75.67 & 9.53 & 95.25 & 66.05 & 17.17 & 4.13 & 13.70 & 6.8 & 41.63 & 11.13 & 9.07 \\
\hline $\mathbf{N}_{4} \mathbf{S}_{2}$ & 64.73 & 75.93 & 9.67 & 93.93 & 66.83 & 17.16 & 4.20 & 13.53 & 6.4 & 42.17 & 10.73 & 10.00 \\
\hline $\mathbf{N}_{4} \mathbf{S}_{3}$ & 63.53 & 74.67 & 9.73 & 95.04 & 66.35 & 17.51 & 4.20 & 13.93 & 6.6 & 43.01 & 10.67 & 10.13 \\
\hline $\mathrm{CD}_{0.05}$ & 0.70 & 0.62 & 0.37 & 0.29 & 2.37 & 1.05 & 0.32 & 0.53 & 0.04 & 1.36 & 0.40 & 0.37 \\
\hline
\end{tabular}


Minimum duration of flowering (7.80 days) was noticed in plants with no nitrogen. Similar results have been obtained by Regar et al., (2016) while working in gladiolus. Among the different spacing used, maximum duration of flowering (9.57 days) was observed at a spacing of $20 \times 30 \mathrm{~cm}$, whereas, it was minimum (8.75 days) in a spacing of $20 \times 20 \mathrm{~cm}$. Due to availability of more nutrients and moisture resulted in better vegetative growth under wider spacing. Better growth may have accelerated photosynthesis during vegetative period. The photosynthates were translocated to various metabolic sinks during reproductive period that might be responsible for prolonged flowering. The interactions of nitrogen and spacing influenced the duration of flowering. Maximum duration (10.33 days) was recorded with plants receiving $30 \mathrm{~g} \mathrm{~N} / \mathrm{m}^{2}$ at a spacing of $20 \times 30 \mathrm{~cm}$. However, minimum duration (7.60 days) was noticed in plants with no nitrogen application with spacing of $20 \times 20$ $\mathrm{cm}$.

From the present study it can be recommended that a basal dose of $5 \mathrm{~kg}$ well rotten farm yard manure (FYM) with half dose of $15 \mathrm{~g} \mathrm{~N} / \mathrm{m}^{2}$ and full amount of phosphorous $\left(30 \mathrm{~g} / \mathrm{m}^{2}\right)$ and potassium (20 $\mathrm{g} / \mathrm{m}^{2}$ ) should be applied to Iris orientalis Mill. cv. 'Frigia' at a spacing of $20 \times 30 \mathrm{~cm}$. Remaining half dose of nitrogen i.e. $15 \mathrm{~g} / \mathrm{m}^{2}$ should be applied after one month of planting.

\section{References}

Bhande, MH., Chopde, N., Lokhande, S. and Wasnik P. 2015. Effect of spacing and corm size on growth, yield and quality of gladiolus. Plant Archives 15:541-544.

Bhatacharjee, SK., Mukherjee, T. and Yadav, LP. 1994. Standardization of agrotechniques in tuberose (Polianthes tuberosa L.). Indian Perfumer 38:144152.

Bijimol, G., and Singh, AK. 2000. Effect of spacing and nitrogen on gladiolus under

Nagaland condition. Journal of Applied Horticulture 4:36-39.

Bijimol, G., and Singh, AK. 2001. Effect of spacing and nitrogen on flowering, flower quality and post-harvest life of gladiolus. Journal of Applied Horticulture 3:48-50.

Chan, AP., 1959. Mineral nutritional studies on carnation. Effect of N, P, K, Ca and temperature on flower production. Proceedings of the American Society for Horticultural Science. 72:473p.

De, LK., and Bhattacharjee, SK. 2003. Advanced Commercial Floriculture. Avishkar publishers and distributors, 2: 353-356.

Dogra, S., Pandey, RK. and Deep, JB. 2012. Influence of gibberellic acid and plant geometry on growth, flowering and corm production in gladiolus (Gladiolus grandiflorus) under Jammu Agro climate. International Journal of Pharmacy and Biological Sciences 3:1083-1090.

Gangwar, APS., Singh, JP. Umrao, VK. and Singh, IP. 2012. Effect of nitrogen and phosphorous with nitrogen sources on vegetative attributes of tuberose. Hort Flora Research Spectrum 4:348-353.

Kadu, AP., Kadu, PR. and Sable, AS. 2009. Effect of nitrogen, phosphorus and potassium on growth, flowering and bulb production in tuberose cv. Single. Journal of Soils and crops 19:367-70.

Khalaj, MA., and Edrisi, B. 2012. Effect of plant spacing and nitrogen levels on quantity and quality characteristics of tuberose (Polianthes tuberosa L.). International Journal of Agri Science 2:244-255.

Kumar, R., Gobind, S. and Yadav, DS. 2002. Studies on $\mathrm{N}$ and $\mathrm{P}$ requirement of tuberose (Polianthes tuberosa L.) cv. 'Single' in hilly soils. Haryana Agriculture University Journal Research 
31: 52-54.

Kumar, S., and Singh, RP. 1998. Effect of nitrogen, bulb and spacing on bulb and bulblet production of tuberose (Polianthes tuberosa L.). South Indian Hoticulture 46: 294-298.

Lehri, SM., Kurd, AA., Rind, MA. and Bangulzai, NA. 2011. The response of Gladiolus tristis L. to $\mathrm{N}$ and $\mathrm{P}_{2} \mathrm{O}_{5}$ fertilizers. Sarhad J. Agric. 27:85-188.

Munikrishnappa, PM., 1996. Influence of Fertigation with Major Micronutrient on Growth, Yield and Oil content in Tuberose (Polianthes tuberosa L.) cv. 'Single'. MSc (Ag.) Thesis. University of Agricultural Sciences, Bangalore, Karnataka (India).

Padaganur, VG., Mokashi, AN., Patil, VS. 2005. Effect of growth regulators on growth and yield of tuberose cv. 'Single'. Karnataka Journal of Agricultural Sciences 182:469-473.

Patel, MM., Parmar, PB. and Parmar, BR. 2006. Effect of nitrogen, phosphorous and spacing on growth and flowering in tuberose (Polianthes tuberosa Linn.) cv. 'Single'. Journal of Ornamental Horticulture 9:286-289.

Ram, M., Pal, V., Singh, MK. and Kumar, M. 2012. Respose of different spacing and salicyclic acid levels on growth and flowering of gladiolus (Gladiolus grandiflora L.). Hort Flora Spectrum 1:270-273.

Ramachandrudu, K., and Thangam, M. 2007. Effect of planting spacings on vegetative growth, flowering and corm production in gladiolus. Journal of Ornamental Horticulture 10:67-68.

Rani, N., Kumar, R. and Dhatt, K. 2005. Effect of nitrogen levels and growing media on growth, flowering and bulb production of Lilium cultivars. Journal of Ornamental Horticulture 8:36-40.

Regar, AL., Thumar, BV., Mahawer, SL. and Meena, NK. 2016. Effect of spacing and nitrogen on floral and vase life parameter of gladiolus (Gladiolus grandiflorus L.) cv. 'American Beauty'. An International Quarterly Journal of Life Sciences 11: 539-542.

Sanjib, S., Talukdar, MC., Sharma, S., Misra, RL. and Sanyat, M. 2000. Effect of time, spacing and depth of planting on gladiolus. Floriculture Research Trend in India 7: 243-245.

Scott, P. 2008. Mineral nutrition of plants. In: Physiology and Behavior of Plants, Wiley, New York. 75-87.

Sheoran, S., Beniwal, BS., Dudi, OP. and Dalal, RS. 2016. Effect of nitrogen and spacing on flower yield and bulb production of tuberose cv. 'Prajwal'. Annals of Agri Bio Research 21:155-159.

Tyagi, AK., Sharma, RK. and Yadav, SK. 2008. Effect of bulb size, spacing and depth of planting on growth and flowering of tuberose (Polianthes tuberosa L.) cultivar 'Single'. Prog. Agri. 8:281-282.

Yadav, MP., and Singh, HK. 1996. Influence of corm size and their spacing on growth and $b$ flowering of gladiolus cv. 'Sylvia'. Progressive Horticulture 28:96-100.

\section{How to cite this article:}

Tamanna Verma, B.P. Sharma and Mallika Thakur. 2019. Effect of Different Nitrogen Levels and Spacing on Growth and Flowering of Iris (Iris orientalis Mill.) cv. 'Frigia'. Int.J.Curr.Microbiol.App.Sci. 8(05): 2101-2109. doi: https://doi.org/10.20546/ijcmas.2019.805.245 